\title{
QUANTITATIVE COMPARISON OF SINKHOLE GEOMORPHOLOGY OF FOUR KARST REGIONS IN OHIO
}

\author{
Douglas Aden \\ Ohio Department of Natural Resources, Division of Geological Survey, 2045 Morse Rd., Bldg. C, Columbus, Ohio, \\ 43229, USA, Douglas.Aden@DNR.Ohio.gov
}

\begin{abstract}
The Ohio Geological Survey has mapped karst in Ohio since 2009. Field mapping of sinkholes has suggested that geomorphological parameters vary between the Bellevue, Delaware, Hillsboro, and Springfield karst regions. Statistical tests confirm that these parameters distinguish the four regions. An understanding of how they differ and what causes those differences can be used to better manage these karst features.
\end{abstract}

Differences between sinkholes within each region were quantified using nine parameters derived from digital elevation model (DEM) analysis. These parameters included: depth, perimeter, area, volume, length of major and minor axes, eccentricity, circularity index, and orientation of karst features. Of these parameters, orientation was displayed on rose diagrams and the others were graphed on boxplots. The Conover-Iman (CI) test was used to determine if parameters were statistically distinct $(\alpha=0.05)$ between karst regions.

Bellevue has the largest sinkholes in the state and differs statistically from other regions by perimeter, area, volume, major axis, and minor axis. Delaware has the deepest sinkholes, and depth is statistically distinct from all other regions except Springfield. Springfield has the smallest number of sinkholes, and no parameter distinguishes Springfield from all other regions. Hillsboro has the smallest mean sinkhole size, but the most sinkholes. Sinkholes in Hillsboro are also statistically more circular than other regions as shown by eccentricity, and circularity index. Three of the four karst regions show alignment with structural lineaments. The exception is the Hillsboro region, where sinkholes are very circular and exhibit no preferred orientation.

Variations in sinkhole size, shape, and distribution are influenced by multiple factors. For example, dissolution in the four regions is influenced by bedrock type, with increasing solubility from dolomite to limestone to evaporites. Sinkholes in Bellevue may be highly developed because Bellevue is underlain by evaporites. Bellevue also experienced multiple events that likely lead to increased bedrock fracturing and water availability from melting ice. Conversely, most of Hillsboro was glaciated only once and has less-developed sinkholes. Unlike other regions, Bellevue was affected by ancient lakes as well. Large sinks in Bellevue indicate higher dissolution activity and sinkholes that have merged, while small circular sinkholes in Hillsboro are less active and not developed enough to merge and become irregular. Improved knowledge of the differences between these regions will assist in mitigating and avoiding these geologic hazards.

\section{Introduction}

Karst has been studied in Ohio for many years. White's 1926 publication, The Limestone Caves and Caverns of Ohio, laid the groundwork for karst mapping in Ohio and established that the fracture caves of northern Ohio are preglacial. Dissolution of these features likely began soon after bedrock deposition (Forsyth, 1988). Some early karst mapping was completed in Bellevue by Tintera (1980), and from 1981 to present, many caves have been mapped and studied by the Wittenberg University Speleological Society. As early as the 1980s, cursory karst mapping was conducted for potential site selection of the Superconducting Super Collider and storage of low-level nuclear byproducts (Pavey et al., 1999). Cataloging karst features is essential for multiple health and safety reasons. Sinkholes channel surface water directly into groundwater, spreading pollution from the surface and causing flooding during heavy storms. In 2008, severe karst-related flooding in Bellevue, Ohio, brought attention to karst as a geologic hazard and provided impetus for detailed karst mapping (Raab et al., 2009; Pavey et al., 2012).

Since 2009, the Ohio Geological Survey has been field mapping karst features and sinkholes in Ohio with funding from the United States Geological Survey Great Lakes Geologic Mapping Coalition. The focus 
has been on detailed field mapping and identifying karst features in Delaware (Aden et al., 2011), Springfield (Aden, 2012), Bellevue (Aden, 2013; Aden, 2014), and Hillsboro (Aden, 2015; Aden, 2016) (Figure 1).

Sinkholes have been analyzed geomorphologically by size and shape (Brinkmann et al., 2008; Weishampel et al., 2011; Basso et al., 2013, Doctor and Young, 2013; Aguilar et al., 2016), by examining alignment and the relationship to bedrock structure (Florea, 2005), and by clustering (Gao et al., 2005).

Empirical field observations by the Ohio Geological Survey indicate that the geometries of sinkhole features in four karst regions in Ohio are distinct from one another. The most noticeable observed distinctions are in sinkhole density, shape, and volume among the regions. To better understand how local geology, glacial history, and hydrologic conditions affect karst development, this study quantitatively compares sinkhole geomorphology and distribution within these four karst regions using the Conover-Iman statistical test and nearest neighbor analysis.

\section{Study Area}

The four Ohio karst regions included in this study are Bellevue, Delaware, Springfield, and Hillsboro, which are named based on their largest city (Figure 1). The regions overlie Devonian, Silurian, and Ordovician-age dolomites, limestones, and evaporites (Hobbs, 2009), which are susceptible to increasing degrees of dissolution. Within the regions, sinkholes are present where glacial drift is thin.

The Bellevue region is $776 \mathrm{~km}^{2}$. Empirical field observations indicate that the Bellevue region has large, irregularly shaped complex sinkholes. Regional drainage is controlled by karst to the extent that there are almost no natural surface streams and most runoff drains into sinkholes. Thin drift, averaging $4.4 \mathrm{~m}$ thick over sinkholes, overlies the Devonian-age Columbus and Delaware Limestones. The limestones are underlain by the Silurian-age Bass Islands Dolomite and the dissolution-prone anhydrites and gypsum of the Salina Group. The Quaternary-age deposits are Wisconsinan lacustrine sand, lake-plane moraine, lacustrine and beach sand, and ground moraine (Pavey et al., 1999). Maximum relief in the region is $117 \mathrm{~m}$.

The Delaware region is the largest study area at $1,020 \mathrm{~km}^{2}$. Drift that overlies sinkholes averages $4.5 \mathrm{~m}$ thick. Sinkholes tend to be linear and are developed in the Silurian- age Salina group and the Devonian-age Columbus and Delaware Limestones. The most notable dissolution cave in the Delaware Limestone is Olentangy Indian Caverns. Quaternary-age deposits are primarily Wisconsinan end moraine and ground moraine (Pavey et al., 1999). Maximum relief in the region is $86 \mathrm{~m}$.

The Springfield region is the smallest study area, has the least amount of sinkholes, and encompasses only $384 \mathrm{~km}^{2}$. The majority of karst is in the Silurian-age Cedarville, Springfield, and Euphemia Dolomites. Fewer features are found within the Silurian-age Massie Shale, Laurel Dolomite, Osgood Shale, Dayton Limestone, Brassfield Limestone, and Ordovician-age limestones and shales. The Quaternary-age deposits are primarily Wisconsinan ground moraine (Pavey et al., 1999). Thin drift is typically less than $6.5 \mathrm{~m}$ thick where sinkholes are located. Maximum relief in the region is $94 \mathrm{~m}$.

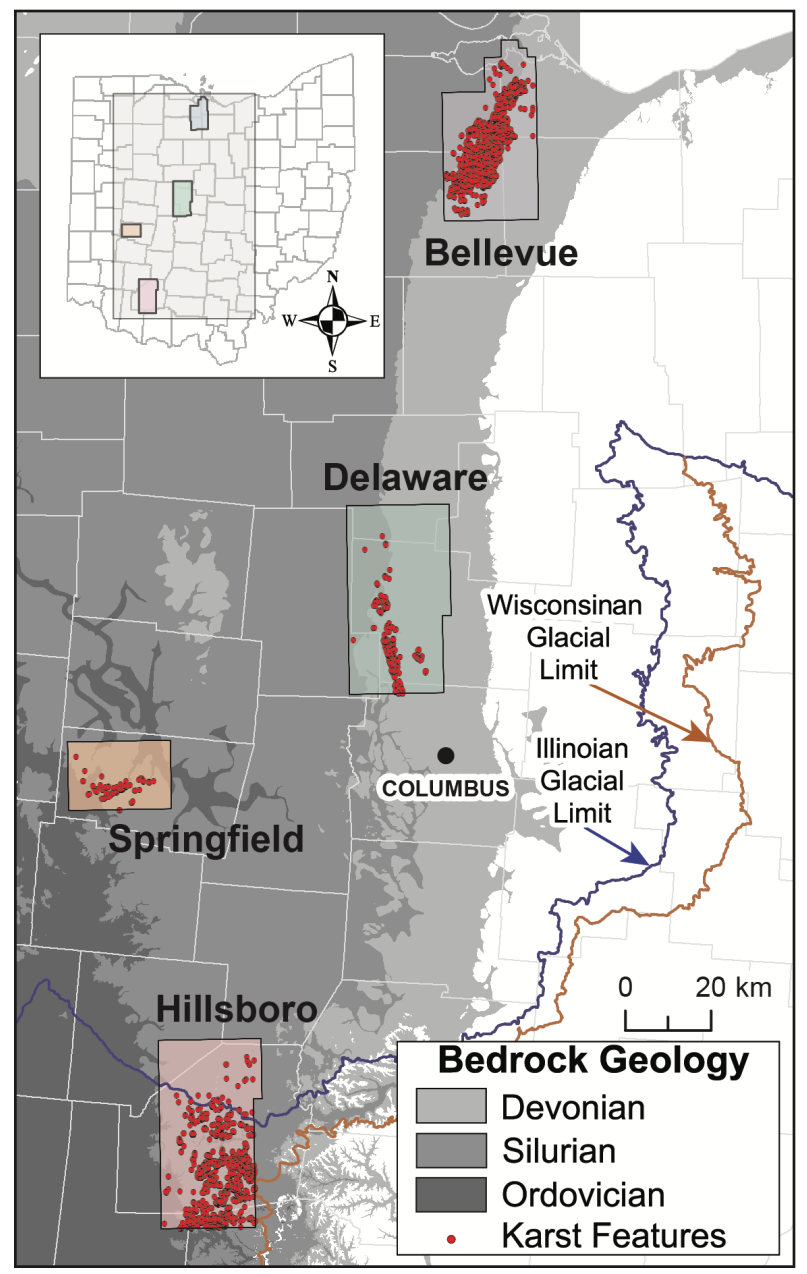

Figure 1. Locations of the four karst regions in Ohio where mapping is complete. 
The Hillsboro region is the second largest study area at $996 \mathrm{~km}^{2}$. Field observations reveal that the sinkholes are relatively small and circular, usually not complex, and typically are located in clusters in the uplands bluffs above stream valleys. Most sinkholes are found in the Silurian-age Tymochtee, Greenfield, and Peebles Dolomites, Lilley Formation, and Bisher Formation. Some karst is present also in the lower Silurian- and Ordovician-age carbonates. The Quaternary-age deposits are primarily Wisconsinan end and ground moraine and dissected Illinoian ground moraine (Pavey et al., 1999). This region was first glaciated by Illinoian ice and then partly by Wisconsinan ice (Figure 1). The majority of the karst features are found in the area that was only glaciated during the Illinoian. Drift thickness typically is less than $3.8 \mathrm{~m}$ where sinkholes are found. Maximum relief in the region is $211 \mathrm{~m}$.

\section{Methodology}

Potential sinkholes were identified in GIS and field verified. Then the geomorphological parameters were measured in GIS to provide data for statistical analysis and differentiation of karst regions.

The DEM used for analysis was created from 2006 light detection and ranging (LiDAR) data and has $0.76 \mathrm{~m}$ horizontal and $0.15 \mathrm{~m}$ vertical accuracies. The DEM was processed to identify potential karst by filling lows and then subtracting the filled DEM from the original unfilled DEM. This new DEM was converted to polygons and adjacent polygons were dissolved. Polygons unrelated to sinkholes were removed using aerial photography and field checking, and the remaining polygons represent the area of each sinkhole. Sinkholes are defined as internally draining, enclosed depressions, which develop through bedrock dissolution. Sinkholes artificially split by roads or ditches on the DEM were considered to be a single sinkhole and were processed as such.

Field verification was important to confirm the existence of sinkholes identified using GIS and to locate additional sinkholes that were too small or too recent to appear on the DEM. Sinkholes discovered in the field were added to the dataset as point locations but could not be used for geomorphological analysis. In total, $91 \%$ of the sinkholes used for analysis were field checked and of those, $72 \%$ were confirmed as karst and $28 \%$ were suspected to be karst.
Geomorphological parameters for the sinkholes in each of the four regions were calculated in GIS and plotted on boxplots. These measurements include depth, perimeter, area, volume, length of major and minor axes, eccentricity, circularity index, and orientation (Table 1). Sinkhole point locations were analyzed for clustering by determining the average nearest neighbor distance and then comparing the expected distance to the actual distance (Gao et al., 2005). Finally, a kernel density raster was generated to assess how sinkhole point locations cluster in the different regions, but these data did not have a substantial role in the comparative analysis of the regions.

The distribution of the data for the parameters in each of the sinkholes was analyzed in the statistical programming language R (R Core Team, 2017) using built-in statistical tests and plotted using the libraries ggplot2, scales (Wickham, 2009), circular, and rose.diag (Agostinelli and Lund, 2013). The Shapiro-Wilk test (Shapiro and Wilk, 1965; Razali and Wah, 2011) and quantile-quantile plots were used on each of the nine parameters for each of the four regions to determine the type of data distribution. These tests indicated that the data are not normally distributed and therefore nonparametric tests were applied. Note that the Shapiro-Wilk and other similar tests do not work well for sample sizes $\leq 30$ (Razali and Wah, 2011), and Springfield has 30 sinkholes.

\begin{tabular}{|c|c|c|}
\hline Parameter & \begin{tabular}{|l|} 
Definition \\
\end{tabular} & Calculation Method \\
\hline Depth (m) & \begin{tabular}{|c|} 
Difference beween bottom \\
elevation and spill over elevation \\
within the sink
\end{tabular} & $\begin{array}{l}\text { Zonal Statistics as a Table } \\
\text { (range) in ArcGIS }\end{array}$ \\
\hline Perimeter $(\mathrm{m})$ & $\begin{array}{c}\text { Length of the sinkhole boundary } \\
\text { at the spill over elevation }\end{array}$ & $\begin{array}{c}\text { Zonal Geometry as a Table in } \\
\text { ArcGIS }\end{array}$ \\
\hline Area $\left(\mathrm{m}^{2}\right)$ & $\begin{array}{l}\text { Each sink with the boundary } \\
\text { defined by the elevation of the } \\
\text { spill over point }\end{array}$ & $\begin{array}{l}\text { Zonal Geometry as a Table in } \\
\text { ArcGIS }\end{array}$ \\
\hline Volume $\left(\mathrm{m}^{3}\right)$ & $\begin{array}{c}\text { How much a sink would hold if it } \\
\text { were hypothetically flooded to } \\
\text { the spill over elevation }\end{array}$ & $\begin{array}{c}\begin{array}{c}\text { Zonal Statistics as a Table using } \\
\text { sum based on difference DEM } \\
\text { in ArcGIS }\end{array} \\
\end{array}$ \\
\hline Major Axis (m) & $\begin{array}{l}\text { Longest length of an idealized } \\
\text { ellipse fit to the sink }\end{array}$ & $\begin{array}{l}\text { Zonal Geometry as a Table in } \\
\text { ArcGIS }\end{array}$ \\
\hline Minor Axis (m) & $\begin{array}{c}\text { Width of an idealized ellipse fit } \\
\text { to the sink }\end{array}$ & $\begin{array}{c}\text { Zonal Geometry as a Table in } \\
\text { ArcGIS }\end{array}$ \\
\hline $\begin{array}{l}\text { Elliptical } \\
\text { Eccentricity }\end{array}$ & $\begin{array}{l}\text { Ranges between } 0 \text { (a circle) and } 1 \\
\text { (a completely elongated ellipse; a } \\
\text { line) (Doctor and Young, 2013) }\end{array}$ & $\sqrt{1-\frac{(\text { minor axis } / 2)^{2}}{(\text { major axis/2 })^{2}}}$ \\
\hline $\begin{array}{l}\text { Circularity } \\
\text { Index }\end{array}$ & $\begin{array}{l}\text { Given the sinks known area, what } \\
\text { would the perimeter be if it were } \\
\text { a perfect circle, then compare } \\
\text { that to its actual perimeter } \\
\text { (Doctor and Young, 2013) }\end{array}$ & $\begin{array}{c}\text { expected perimeter }= \\
2 \pi \sqrt{ } \text { area/ } \pi \text { and Circularity } \\
\text { index }=(((\text { perimeter-expected } \\
\text { perimeter }) V(\text { expected } \\
\text { perimeter }))+1\end{array}$ \\
\hline $\begin{array}{c}\text { Orientation in } \\
\text { degrees }\end{array}$ & $\begin{array}{l}\text { The main direction each sink } \\
\text { trends along }\end{array}$ & $\begin{array}{c}\text { Calculate Polygon Main Angle } \\
\text { in ArcGIS }\end{array}$ \\
\hline
\end{tabular}

Table 1. Definitions of the geomorphological parameters and how they were calculated. 
Kruskal-Wallis tests (Kruskal and Wallis, 1952) were performed to determine if a geomorphological parameter for at least one of the four regions is statistically distinct from another. In all cases, the test was significant at $\alpha=0.05$, indicating that at least one region is distinct from the others for each of the nine parameters. To determine which parameters are distinct for each region, a series of post hoc Conover-Iman (CI) tests $(\alpha=0.05)$ (Conover and Iman; 1979; Dinno, 2017) were performed using the BenjaminiYekutieli (2001) adjustment to control the false discovery rate. Note that the CI test is a one-sided test, so $p$-values had to be less than $\alpha / 2$ to show median difference.

Of the eight parameters analyzed (CI test) and plotted on boxplots, three were selected as representative and are shown below. On the boxplots, the center line of the box represents the median (McGill et al., 1978) and the mean (white diamond) is included to show the significance of the outliers.

\section{Results}

Sinkholes cover $27.90 \mathrm{~km}^{2}$ of the total $3,176 \mathrm{~km}^{2}$ included in the four regions. Almost $97 \%$ of the sinkholes are in the Bellevue region by area. The four regions include 2,635 sinkholes that are measurable on the DEM, and 5,091 total karst points that include caves springs and sinkholes not on the DEM.

\begin{tabular}{|c|c|c|c|}
\hline & Bellevue & Delaware & Springfield \\
\hline $\begin{array}{l}\frac{0}{\circ} \\
\text { 을 } \\
\overline{\underline{x}}\end{array}$ & $\begin{array}{c}\text { depth, } \\
\text { perimeter, area, } \\
\text { volume, major } \\
\text { axis, minor axis, } \\
\text { orientation, } \\
\text { eccentricity, } \\
\text { circularity index }\end{array}$ & $\begin{array}{c}\text { depth, } \\
\text { perimeter, } \\
\text { area, volume, } \\
\text { major axis, } \\
\text { orientation, } \\
\text { eccentricity, } \\
\text { circularity index }\end{array}$ & $\begin{array}{c}\text { eccentricity, } \\
\text { circularity index }\end{array}$ \\
\hline 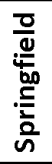 & $\begin{array}{c}\text { perimeter, area, } \\
\text { volume, major } \\
\text { axis, minor axis }\end{array}$ & N/A & \\
\hline $\begin{array}{l}\frac{2}{\pi} \\
\frac{\pi}{\pi} \\
\frac{\pi}{0}\end{array}$ & $\begin{array}{c}\text { depth, } \\
\text { perimeter, area, } \\
\text { volume, major } \\
\text { axis, minor axis, } \\
\text { eccentricity }\end{array}$ & & \\
\hline
\end{tabular}

Table 2. Results of the Conover-Iman test showing which parameters are statistically distinct when comparing regions.
Several analyses demonstrate how each region is distinct (Tables 2, 3). Conover-Iman results, selected boxplots, and rose diagrams depict the differences between geomorphological parameters for each region (Figures 2-6).

Some parameters statistically distinguish one region from all others. For example, Bellevue had the largest sinkholes in the state and is statistically distinct (CI test) from the other regions by perimeter, area (Figure 2), volume, major axis, and minor axis. Bellevue also has

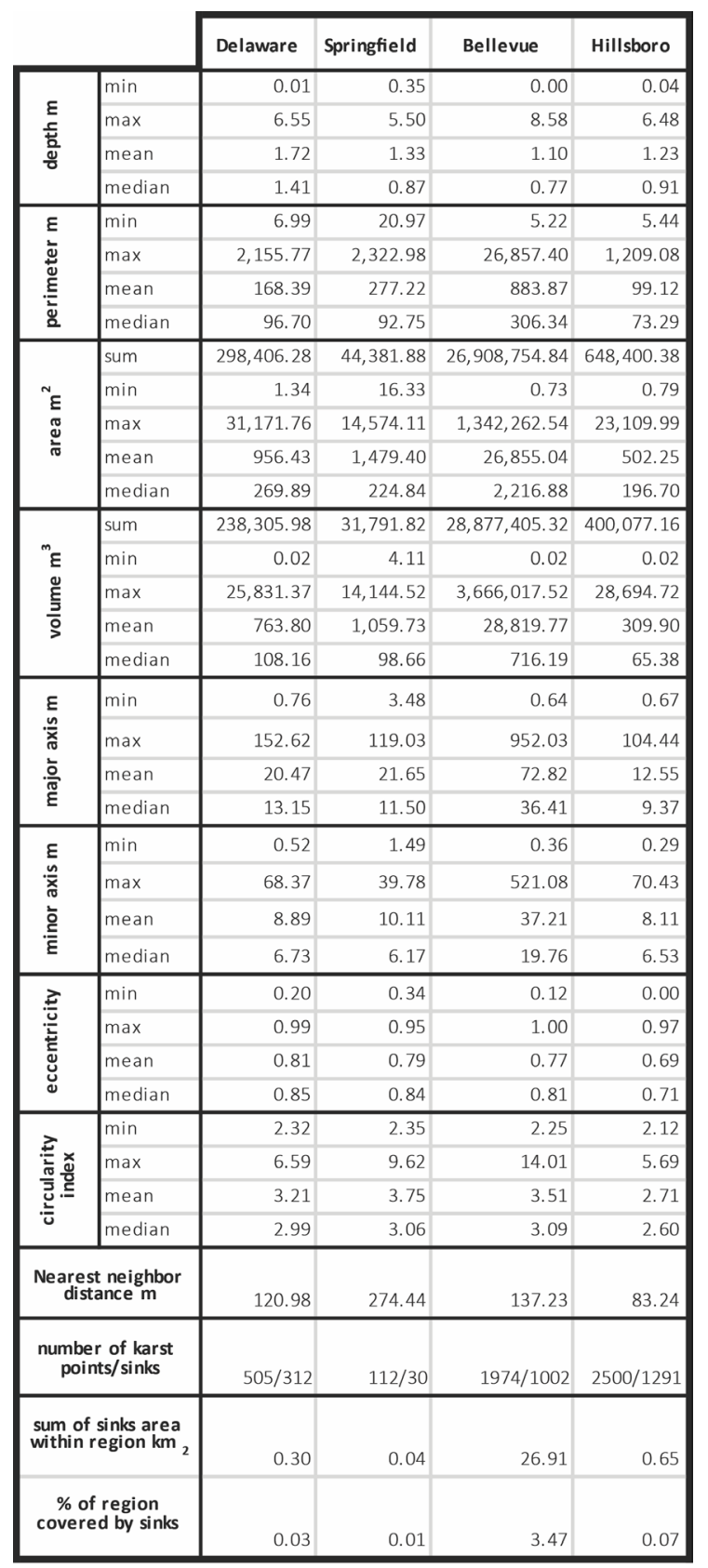

Table 3. Results of the geomorphological, clustering, and area analyses. 
the largest maximum values for all eight parameters, as well as the largest mean and median values for all parameters except for depth, eccentricity, and circularity index (Table 3). Note that although orientation was used for statistical comparisons, it is excluded from Table 3 because it is a different data type.

Sinkholes in Hillsboro are more circular than the other regions, and eccentricity (Figure 3 ) and circularity index were statistically distinct (CI test) from the other regions. Hillsboro has the smallest mean and median values for all parameters on Table 3 except for depth. These results quantitatively confirmed field observations that sinkholes here are small and circular.

Other parameters distinguish one or two regions but not all three (Table 2). For example, nine parameters distinguish Hillsboro from Bellevue, and eight distinguish Delaware from Hillsboro. Springfield can be distinguished from Hillsboro and Bellevue by perimeter and major axis length. Delaware had the deepest mean sinkholes (Figure 4), and depth was statistically distinct (CI test) from Bellevue and Hillsboro but not Springfield. The sinkholes in Delaware are $1 \mathrm{~m}$ deeper than Springfield and Hillsboro and $2 \mathrm{~m}$ deeper than Bellevue. However, since Springfield had the least data, no parameter statistically distinguished (CI test) Springfield from Delaware.

Orientation also varies by region (Figure 5). In Bellevue and Delaware, the dominant sink orientation is ENE to

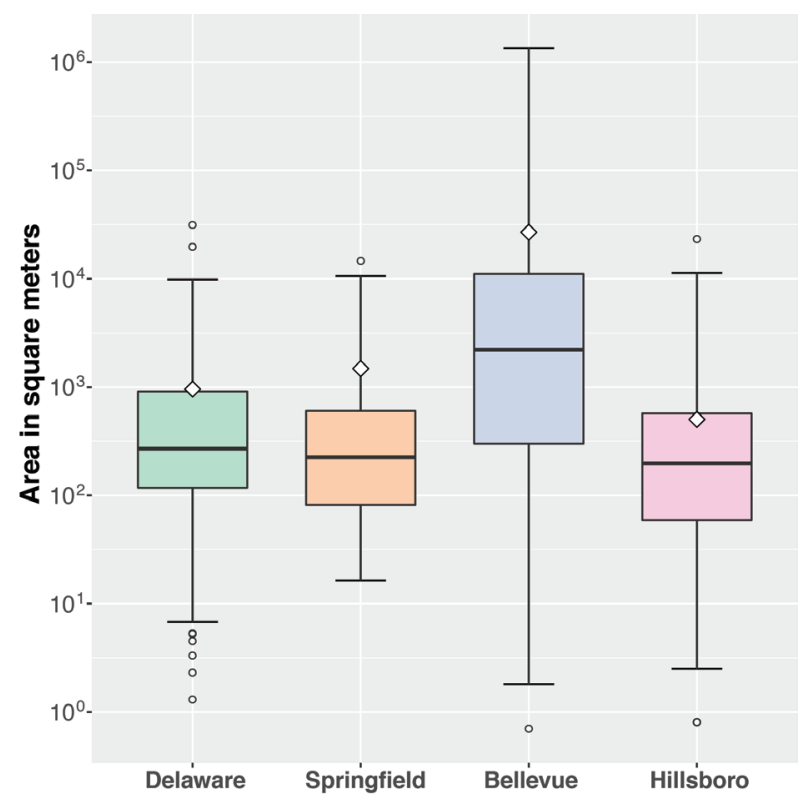

Figure 2. Boxplots comparing area (log 10 scale).
WSW, while Springfield is NWN to SES. On the other hand, the sinks in Hillsboro (Figure 5) are very circular, strongly reflected by the lack of preferred orientation in the rose diagram.

Nearest neighbor analysis confirms $(\alpha=0.05)$ that karst features in all four regions cluster to differing degrees as measured by the nearest neighbor distances (Table 3 ). Kernel density shows that in Bellevue, few sinkholes cluster based on distance, but many cluster within the same large depression. Hillsboro is the opposite; many sinkholes cluster based on distance, but very few are within the same depression because the sinks are so small. Hobbs (2009) reports that Bellevue contains the highest sinkhole density in Ohio. While this is certainly true based on sinkhole area, the Hillsboro region contains many more individual sinkholes.

\section{Discussion}

The Bellevue region is statistically distinct (CI test) from other karst regions in Ohio. Bellevue sinkholes are an order of magnitude larger in mean area, perimeter, and volume than those found in other regions. Previous studies have suggested that depressions in Bellevue are so large because the region is underlain by very soluble gypsum (Sasowsky et al., 2003; Dinsmore, 2011). Parts of the Salina Group were deposited as anhydrite and chemically altered to gypsum, resulting in expansion (White, 1926; Kihn, 1988; Pavey et al., 1999). This expansion likely fractured the surrounding Columbus

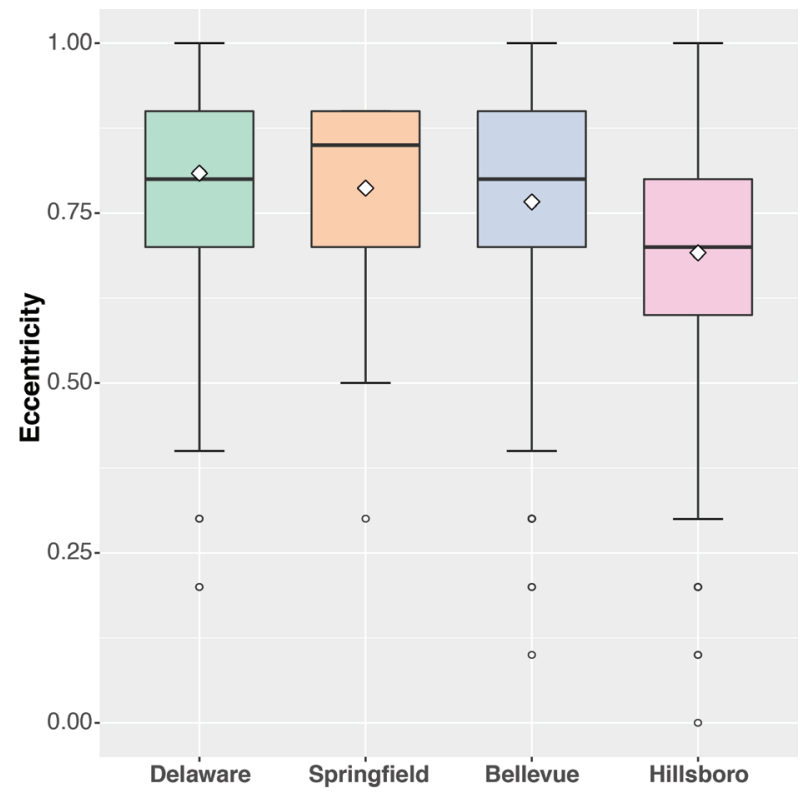

Figure 3. Boxplots comparing eccentricity. 


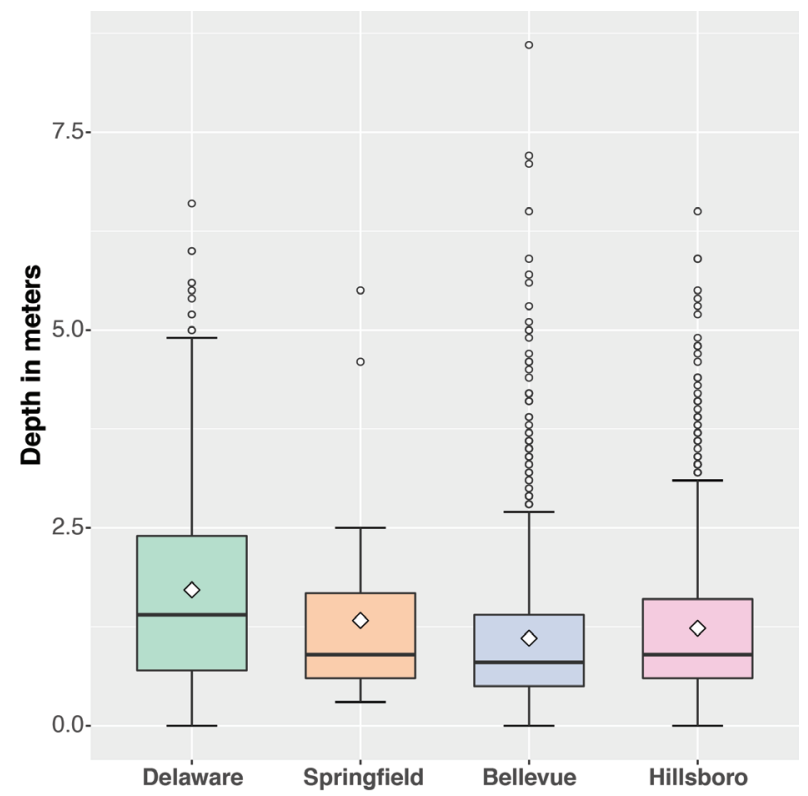

Figure 4. Boxplots comparing depth.
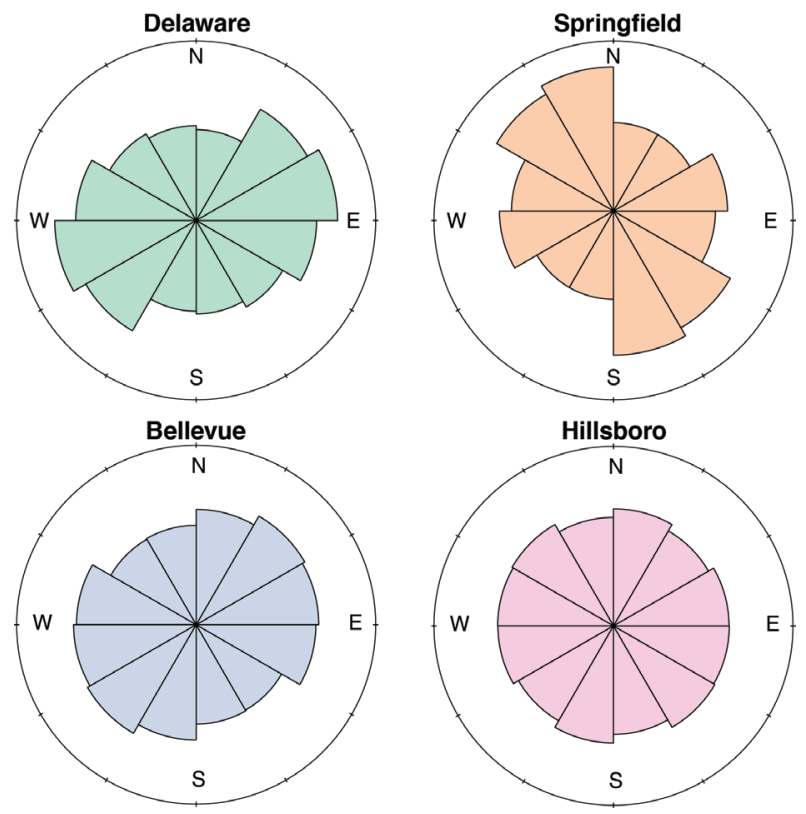

Figure 5. Rose diagrams showing orientation.

Limestone, facilitating collapse after subsequent gypsum dissolution (Dinsmore, 2011). This region also includes many caves, such as Seneca Caverns, that are thought to have formed by dissolution and collapse of evaporites (White, 1926; Kihn, 1988; Dinsmore, 2011). Gypsum is approximately 100 times more soluble than carbonate rocks, so karst in gypsum develops more rapidly (Gutiérrez et al., 2014). This same underlyingevaporite influence is not present in the other regions and appears to be the primary cause of the large features in Bellevue. Bellevue is also characterized by large, upwelling springs in the north known as blue holes, the water chemistry of which has been linked to dissolution of anhydrite and gypsum (Sasowsky et al., 2003).

Bellevue also experienced more cycles of glaciation than other regions, especially compared to Hillsboro. Anderson and Hinds (1997) provide an example of glacial loading and unloading, leading to increased dissolution in an evaporite environment, with rebound potentially increasing fracture size and connectivity. Increases in glacial melt water volume can also increase dissolution (Anderson and Hinds, 1997; Gutiérrez et al., 2014), which could be compounded by fractures created over multiple glaciation events.

Furthermore, Bellevue was flooded during the Wisconsinan by Lake Maumee, an ancient lake that was located where Lake Erie is now (Forsyth, 1959; Calkin and Feenstra, 1985). During this time, $86 \%$ of present Bellevue sinkholes would have been under water. As Lake Maumee and later ancient lakes receded, a series of sandy beach ridges were deposited (Forsyth, 1959). This beach-ridge sand is poorly consolidated relative to typical clay-rich tills and can subside quickly when dewatered by groundwater fluctuations (Ford and Williams, 2007). This sand also has a higher hydraulic conductivity, perhaps allowing for increased infiltration. The presence of this sand, along with the occurrence of evaporites and history of glaciation, may be why the largest sinkholes are found in the Bellevue region (Dinsmore, 2011).

Sinkholes in the Hillsboro region are statistically distinct (CI test) from the other regions by their circularity and from Bellevue and Delaware by their small size. Sinkholes are usually circular when they first form (Brinkmann et al., 2008). Therefore, karst regions with circular sinkholes are relatively less developed. The majority of Hillsboro was influenced only by the Illinoian glaciation, reducing exposure to melt water, loading cycles, and the resulting fracturing. Over time, sinkholes merge together (Brinkmann et al., 2008; Aguilar et al., 2016) and preferentially erode, forming large irregular depressions. Unlike in Delaware and Bellevue, sinkholes in Hillsboro are highly circular and formed in dolomites. Dolomite has a much lower dissolution rate than limestone (Liu et al., 2005) or evaporites. The high degree of circularity, small size, low rate of dolomite bedrock dissolution, and reduced glacial influence all suggest the sinkholes in Hillsboro are less developed than others in the state. 
The Delaware region has the most linear sinkholes of the four regions as measured by mean eccentricity, and is statistically distinct (CI test) from all but Springfield. A sinkhole eccentricity of greater than 0.98 has been suggested to distinguish between linear artificial features, such as ditches, and natural sinkholes (Doctor and Young, 2013 ). Only $0.7 \%$ of sinkholes are above this value, but some of these are definitive sinkholes, one of which is directly over Olentangy Indian Caverns in the Delaware region. However, eliminating thousands of non-sinkhole linear depressions may outweigh the exclusion of a few valid sinkholes. A similar method of assessing sinkhole shape is circularity index. Doctor and Young (2013) propose a maximum value of 1.7 to eliminate linear, anthropogenic features; this would remove $23 \%$ of the sinkholes. Note that the sinkholes with a circularity index above 5 are bisected by roads or drainages, which artificially increase their irregularity. Urbanization increases runoff (Ford and Williams, 2007) and sinkholes in the Delaware region are statistically distinct (CI test) from Bellevue and Hillsboro as the deepest and most linear, perhaps exacerbated by their presence in a rapidly developing suburban area. Reevaluating these features in the future could help assess their rate of change.

The low density of sinkholes in the Springfield region could be a result partly of the dissolution-resistant dolomite bedrock, but also owing to thick glacial till in parts of the region. Even though Springfield has only 30 sinkholes, it can still be distinguished from Hillsboro and Bellevue.

Some observations apply to all four regions. For example, sinkhole orientation typically is controlled by the direction of fractures in the bedrock (Florea, 2005; Gao et al., 2005) because they focus dissolution along planes of weakness. Some lineaments, indicative of bedrock structure, have been mapped in Ohio (Struble and Hodges, 1980; Wickstrom et al., 1992). In Bellevue, Delaware, and Springfield, lineaments generally align with the trends shown on the rose diagram (Figure 5). Hillsboro is a slight exception because the sinkholes are circular and have not yet developed enough to indicate an orientation on the DEM.

Data analyses that involve statewide remote sensing and large aggregated datasets always present challenges and limitations. One limitation of DEM-based geomorphological analysis is that only the features that are represented on the DEM can be analyzed by size and shape. This excludes 2456 karst features located by field work that were too small or recent to appear on the DEM. Collecting new LiDAR data will allow these and other features to be detected, thus improving the precision of these statistics and further illuminate differences between the regions. Additional data would also improve the statistical significance of the Springfield region, allowing for a more thorough analysis. Until then, sinkholes discovered in the field were only used for clustering analysis.

Some sinkholes have not changed significantly since the data was collected, while others have grown or been filled by landowners. In many cases, the DEM does not measure complete sinkhole depth because the deepest part of a sinkhole is often a small, open fracture below the DEM resolution. Excluding those that were filled, nearly every sinkhole visited was deeper than shown on the DEM. Depth, area, perimeter, and volume should be considered minimums, because erosion only makes sinkholes larger over time.

\section{Conclusions}

Statistical tests confirm empirical field observations and show that geomorphological parameters distinguish the karst regions of Ohio. The large and irregular sinkholes in Bellevue are potentially linked to increased bedrock fracturing and melt water associated with Ice Age glaciers and to the influence of underlying gypsum. By contrast, sinkholes in Hillsboro are small, circular, and clustered likely because of their immaturity, limited glaciation, and less soluble dolomite bedrock. The sinkholes in the Delaware and Springfield regions exhibit characteristics between the extremes of the other two regions. In the Delaware region, ever-increasing urbanization may control depth and linearity of sinkholes. Low sinkhole density in Springfield presents challenges when quantitatively compared to other regions. Better understanding of how these sinkholes developed and are distributed among the regions will aid in public recognition and mitigation of these geologic hazards.

\section{Acknowledgements}

This project would not have been possible without the support of the United States Geological Survey, Great Lakes Geologic Mapping Coalition. Thanks go to Paul Spahr for helping formulate this research and to Brittany Parrick and many others who assisted with field work and persisted regardless of the weather. 


\section{References}

Aden DJ. 2012. Karst of Springfield, Ohio. Columbus $(\mathrm{OH})$ : Ohio Department of Natural Resources, Division of Geological Survey Open-File Report 2012-2.

Aden DJ. 2013. Karst of the Bellevue Quadrangle and portions of the Clyde and Castalia Quadrangles. Columbus (OH): Ohio Department of Natural Resources, Division of Geological Survey OpenFile Report 2013-1.

Aden DJ. 2014. Karst of the Fireside Quadrangle and portions of the Flat Rock and Clyde Quadrangles. Columbus (OH): Ohio Department of Natural Resources, Division of Geological Survey OpenFile Report 2014-1.

Aden DJ. 2015. Karst of the Hillsboro, New Market, New Vienna, and Leesburg Quadrangles, Ohio: Columbus (OH): Ohio Department of Natural Resources, Division of Geological Survey OpenFile Report 2015-1.

Aden DJ. 2016. Karst of the Belfast and Sugar Tree Ridge 7.5 Minute Quadrangles, Columbus $(\mathrm{OH})$ : Ohio Department of Natural Resources, Division of Geological Survey Open-File Report 2016-4.

Aden DJ, Powers DM, Pavey RR, Jones DM, Martin DR, Shrake DL, Angle MP. 2011. Karst of western Delaware County, Ohio, region. Columbus $(\mathrm{OH})$ : Ohio Department of Natural Resources, Division of Geological Survey OFR 2011-4.

Aguilar Y, Bautista F, Mendoza ME, Frausto O, Ihl T. 2016. Density of karst depressions in Yucatán State, Mexico. Journal of Cave and Karst Studies, 78 (2): 51.

Agostinelli C, Lund U. 2013. R package 'circular': Circular Statistics (version 0.4-7). [Internet]. 2017. Trento Italy; [cited 2017 September 1]. Available from: https://r-forge.r-project.org/projects/circular.

Anderson NL, Hinds RC. 1997. Glacial loading and unloading: a possible cause of rock salt dissolution in the Western Canada Basin. Carbonates and Evaporites 12 (1): 43.

Benjamini Y, Yekutieli D. 2001. The control of the false discovery rate in multiple testing under dependency. Annals of Statistics 29 (4): 11651188.

Basso A, Bruno E, Parise M, Pepe M. 2013. Morphometric analysis of sinkholes in a karst coastal area of southern Apulia (Italy). Environmental Earth Sciences 70 (6): 2545-2559.

Brinkmann R, Parise M, Dye D. 2008. Sinkhole distribution in a rapidly developing urban environment: Hillsborough County, Tampa Bay area, Florida. Engineering Geology 99 (3-4): 169-184.
Calkin PE, and Feenstra BH. 1985. Evolution of the Eriebasin great lakes. Geological Association of Canada, Special Paper 30: 150-170.

Conover WJ, Iman RL. 1979. On multiple-comparisons procedures. Los Alamos Sci. Lab. Tech. Rep. LA7677-MS.

Dinsmore MA. 2011. Origin and Evolution of Sinkholes on the Bellevue-Castalia Karst Plain, North-Central Ohio [master's thesis]. Akron (OH): University of Akron. 139 p.

Dinno A. 2017. conover.test: Conover-Iman Test of Multiple Comparisons Using Rank Sums. R package version 1.1.4. [Internet]. 2017. Portland State University: CRAN.R-project.org; [cited 2017 September 19]; Available from: https://CRAN.R-project.org/ package $=$ conover.test.

Doctor DH, Young JA. 2013. An evaluation of automated GIS tools for delineating karst sinkholes and closed depressions from 1-meter LiDAR-derived digital elevation data. In: Land L, Doctor DH, Stephenson JB, editors. Sinkholes and the Engineering and Environmental Impacts of Karst: Proceedings of the Thirteenth Multidisciplinary Conference, May 6-10, Carlsbad, New Mexico: NCKRI Symposium 2. Carlsbad (NM) p. 449-458.

Florea LJ. 2005, Using State-wide GIS data to identify the coincidence between sinkholes and geologic structure Journal of Cave and Karst Studies 67 (2): 120-124.

Ford D, Williams PW. 2007. Karst hydrogeology and geomorphology. England: John Wiley \& Sons.

Forsyth JL. 1959. The beach ridges of northern Ohio. Ohio. Division of Geological Survey, Information Circular 25.

Forsyth JL. 1988. The geologic setting of the Erie Islands. In: Downhower JF, editor. The Biogeography of the Island Region of Western Lake Erie. Columbus $(\mathrm{OH})$ : Ohio State University Press. p. 13-23.

Gao Y, Alexander EC, Barnes RJ. 2005. Karst database implementation in Minnesota: analysis of sinkhole distribution. Environmental Geology 47 (8): 1083-1098.

Gutiérrez F, Parise M, De Waele J, Jourde H. 2014. A review on natural and human-induced geohazards and impacts in karst. Earth-Science Reviews 138: 61-88.

Hobbs HH III. 2009. The Glaciated Central LowlandsOhio, In: Palmer AN, Palmer MV, editors. Caves and Karst of the USA. Huntsville, (AL): National Speleological Society, p. 136-140.

Kruskal WH, Wallis WA. 1952. Use of ranks in onecriterion variance analysis. Journal of the American Statistical Assoc. 47 (260): 583-621.

Kihn GE. 1988. Hydrogeology of the Bellevue-Castalia area, north-central Ohio, with an emphasis on 
Seneca Caverns [master's thesis], Toledo $(\mathrm{OH})$ : University of Toledo. $149 \mathrm{p}$.

Liu Z, Yuan D, Dreybrodt W. 2005. Comparative study of dissolution rate-determining mechanisms of limestone and dolomite. Environmental Geology 49 (2): 274-279.

McGill R, Tukey JW, Larsen WA. 1978. Variations of Box Plots. American Statistician 32 (1): 12-16.

Pavey RR, Hull DN, Brockman CS, Schumacher GA, Stith DA, Swinford EM, Sole TL, Vorbau KE, Kallini KD, Evans EE, Slucher ER, Van Horn, RG. 1999. Known and probable karst in Ohio: Columbus (OH): Ohio Department of Natural Resources Division of Geological Survey Map EG-1. [Revised 2002, 2004, 2007.]

Pavey RR, Angle MP, Powers DM, Swinford EM. 2012. Karst flooding in Bellevue, Ohio, and vicinity-2008: Columbus (OH): Ohio Department of Natural Resources, Division of Geological Survey Map EG-5.

R Core Team. 2017. R: A language and environment for statistical computing. Vienna (Austria): R Foundation for Statistical Computing. [Internet]. 2017. Vienna Austria; [cited 2017 September 19] Available from: https://www.R-project.org.

Raab J, Haiker B, Jones W, Angle M, Pavey R, Swinford M, Powers D. 2009. Ground water induced flooding in the Bellevue, Ohio area, spring and summer 2008: Columbus (OH): Ohio Department of Natural Resources, Division of Water Technical Report of Investigation 2009-1.

Razali NM, Wah YB. 2011. Power comparisons of Shapiro-Wilk, Lolmogorov-Smirnov, Lilliefors and Anderson-Darling Tests, Journal of Statistical Modeling and Analytics 2 (1): 21-33.

Sasowsky ID, Dinsmore MA, Salvati R, Bixby R, Raymond H, Mazzeo P. 2003. Subtle but significant karst on the glaciated Bellevue-Castalia Karst Plain, Ohio, USA. In: Beck BF, editor. Sinkholes and the Engineering and Environmental Impacts of Karst. (Proceedings of the Ninth Multidisciplinary Conference), American Society of Civil Engineers Geotechnical Special Publication No. 122, p. 95-109.

Shapiro SS, Wilk MB. 1965. An analysis of variance test for normality (Complete Samples). Biometrika 52 (3-4): 591-611.

Struble RA, Hodges DA. 1982. Landsat Lineament Maps [of Columbus, Marion, Toledo $1 \times 2^{\circ}$ ]. In: Gray JD, Struble RA, Carlton RW, Hodges DA, Honeycutt MF, Kingsbury RH, Knapp NF, Majchszak FL, Stith DA. An integrated Study of the Devonian-age black shales in eastern Ohio.
Washington (DC): US Department of Energy, Technical Information Center Report DOE/ ET/12131-1399. Chapter 7.

Tintera JJ. 1980. The identification and interpretation of karst features in the Bellevue-Castalia region of Ohio [doctoral dissertation]. Bowling Green $(\mathrm{OH})$ : Bowling Green State University. 63 p.

Weishampel JF, Hightower JN, Chase AF, Chase DZ, Patrick RA. 2011. Detection and morphologic analysis of potential below-canopy cave openings in the karst landscape around the Maya polity of Caracol using airborne LiDAR. Journal of Cave and Karst Studies 73 (3): 187-196.

White GW. 1926, The limestone caves and caverns of Ohio. Ohio Journal of Science 26 (2): 73-116.

Wickham H. 2009. ggplot2: Elegant Graphics for Data Analysis. New York (NY): Springer-Verlag.

Wickstrom LH, Drahovzal JA, Keith B. 1992, The geology and geophysics of the east Continent Rift Basin: Indiana Geological Survey Open-File Study $92-04$. 
268 NCKRI SYMPOSIUM 7 15TH SINKHOLE CONFERENCE 